\title{
CAPTURING ENDOTHELIAL CELLS BY CORONARY STENTS - FROM HISTOLOGY TO CLINICAL OUTCOMES \\ Miloje Tomasevic ${ }^{1,2}$, Jelena Rakocevic ${ }^{3}$, Milan Dobric ${ }^{1,4}$, Srđan Aleksandric ${ }^{1}$ and Milica Labudovic ${ }^{3}$ ${ }^{1}$ Clinic of Cardiology, Clinical Center of Serbia, Belgrade, Serbia University of Kragujevac , Faculty of Medical Sciences, Department of Internal Medicine, , Kragujevac, Serbia ${ }^{3}$ Institute of Histology and Embryology “Aleksandar Dj. Kostic”, School of Medicine, University of Belgrade ${ }^{4}$ School of Medicine, University of Belgrade, Belgrade, Serbia
}

\section{HVATANJE ENDOTELNIH ĆELIJA KORONARNIM STENTOVIMA - OD HISTOLOGIJE DO KLINIČKIH ISHODA \\ Miloje Tomašević $\mathfrak{c}^{1,2}$, Jelena Rakočević ${ }^{3}$, Milan Dobrić1,4, Srđan Aleksandrić ${ }^{1}$ i Milica Labudović ${ }^{3}$ ${ }^{1}$ Klinika za kardiologiju, Klinički centar Srbije, Beograd, Srbija \\ 2, Univerzitet u Kragujevcu, Fakultet medicinskih nauka, , Katedra za internu medicine, Kragujevac, Srbija \\ ${ }^{3}$ Institut za histologiju i embriologiju „Aleksandar Đ. Kostić”, Medicinski fakultet, Univerzitet u Beogradu ${ }^{4}$ Medicinski fakultet, Univerzitet u Beogradu, Beograd, Srbija}

\begin{abstract}
Introduction of drug-eluting stents (DES) in the therapy of patients with coronary artery disease resulted in the significant reduction of in-stent restenosis compared to bare-metal stent (BMS) treatment. However, the high incidence of late stent thrombosis with DES emerged as one of the safety concerns after their implantation. Enhancing stent endothelization by improved early healing and neointimal strut coverage emerged as possible solution for this late complication. Endothelial progenitor cells (EPC) capturing stents are designed to promote in situ endothelization with immobilized, antihuman, anti-CD34 antibodies attached to the luminal stent surface. Anti-CD34 antibodies target and capture EPC from circulation, which further differentiate into vascular endothelial cells and form functional endothelial layer on the stent surface. These cells are also capable of secreting pro-angiogenic factors that stimulate local endothelial cells to proliferate and migrate. Preclinical and clinical studies proved feasibility, efficacy and safety of EPC capturing stents in stable and high-risk patients with coronary artery disease. Rapid and extensive endothelization of EPC capturing stents translated into favorable profile of clinical outcomes, comparable to efficacy of BMSs and DESs. Therefore, we here present the most important results from the experimental and clinical studies that explored ECP capturing strategy to enhance endothelization, reduce the incidence of instent thrombosis and improve outcomes of patients with coronary artery disease, along with the future perspectives in this promising therapeutic approach.
\end{abstract}

Keywords: coronary stent, endothelial progenitor cells, drugeluting stent, bare metal stent, coronary artery disease

\section{SAŽETAK}

Primena stentova sa oslobađanjem leka (DES) u terapiji pacijenata sa koronarnom bolešću srca dovela je značajnog smanjenje pojave in-stent restenoze u poređenju sa primenom običnih metalnih stentova (BMS). Međutim, uočena je veća pojava kasne tromboze stenta nakon implantacije DES-a. Rešenje za ovu kasnu komplikaciju bi moglo biti povećanje endotelizacije stenta putem poboljšanja ranog neointimalnog pokrivanja stenta. Stentovi koji „hvataju“ endotelne progenitorske ćelije (EPĆ) kreirani su sa ciljem da pobolišaju in situ endotelizaciju pomoću imobilisanih, antihumanih, anti-CD34 antitela koja su pričvršćena za luminalnu stranu stenta. Anti-CD34 antitela su usmerena na EPĆ koje potom hvataju iz cirkulacije, a EPĆ se dalje diferenciraju u smeru vaskularnih endotelnih ćelija i formiraju funkcionalni sloj endotela na površini stenta. Ove ćelije imaju i sposobnost izlučivanja pro-angiogenih faktora koji stimulišu proliferaciju i migraciju okolnih endotelnih ćelija. Prekliničke i kliničke studije su dokazale efikasnost $i$ bezbednost primene stentova koji „hvataju“ EPĆ kod stabilnih pacijenata sa koronarnom bolešću srca, ali u visoko-rizičnoj grupi pacijenata. Pokazalo se da brza i obimna endotelizacija stentova koji ,,hvataju“ EPĆ daje povoljne kliničke ishode koji se mogu porediti sa ishodima nakon ugradnje BMS i DES. Stoga je cilj ovog rada da predstavimo najvažnije rezultate eksprimentalnih $i$ kliničkih studija koje su ispitivale mogućnost „hvatanja“ EPĆ u cilju poboljšanja endotelizacije, smanjenja učstalosti in-stent tromboze i poboljšanja ishoda pacijenata sa koronarnom bolešću srca, kao i moguće sledeće korake u ovom obećavajućem terapijskom pristupu.

Ključne reči: rana neonatalna sepsa, dijagnoza, terapija

\section{ABBREVIATIONS}

BMS - bare metal stent, DES - drug-eluting stent, EPC - endothelial progenitor cell, PCI - percutaneous coronary intervention, LST - late stent thrombosis,

SES - sirolimus-eluting stent, OCT - optical coherence tomography,

SEM - scanning electron microscopy, MACE - major adverse cardiovascular event, QCA - ..., IVUC, STEMI, TIMI...etc.

\section{sciendo}

DOI: $10.2478 /$ sjecr-2019-0018 


\section{INTRODUCTION}

Percutaneous coronary intervention (PCI) has become the treatment of choice for the majority of patients with coronary artery disease. Despite the efficacy of PCI, with the appearance of bare metal stents (BMS), the rate of in-stent restenosis was reaching up to $30 \%$ of cases $(1,2)$. Immunologic response to the presence of metal stent within coronary circulation, as well as mechanical injury of the vessel wall by the stent deployment, often resulted in neointimal hyperplasia. Vascular smooth muscle cell proliferation, along with the deposition of extracellular matrix, can lead to progressive narrowing and occlusion of blood vessel, so-called in-stent restenosis (3). The introduction of drug-eluting stents (DES) with their antiproliferative properties significantly reduced the growth of neointima and the restenosis rate $(4,5)$. Yet, the consequence of cytotoxic/cytostatic effects of the DES appeared to affect the endothelial cells as well, inhibiting their proliferation, migration and function in the long-term $(6,7)$. This resulted in the occurrence of the late stent thrombosis (LST), one of the safety concerns following the DES implantation $(8,9)$.

Late stent thrombosis in DES is histologically characterized by fibrin deposition, scant presence of smooth muscle cells and incomplete endothelization. Finn et al. (10) proposed that the delayed endothelization is one of the main causes of the late stent thrombosis. Additional proposed mechanism of the late stent thrombosis included hypersensitivity reaction (11), excessive fibrin deposition with malaposition, or neoatherosclerosis (12).

Therefore, enhancing endothelization emerged as an interesting approach in attenuating antiproliferative effects of DES and overcoming the risk of late stent thrombosis. Capturing circulating endothelial cells could be a promising technique, especially in high-risk patients unable to receive dual antiplatelet therapy (DAPT) after stent implantation for longer periods of time.

\section{ENDOTHELIAL PROGENITOR CELLS}

Endothelial progenitor cells (EPC) have first been isolated and described by Asahara et al. (13). These circulating cells derive from the bone marrow, differentiating from their ancestor cell hemangioblast, and express surface cell markers in similar pattern as vascular endothelial cells. EPC are capable of migrating to ischemic or hypoxic regions, where they can adhere to injured endothelium and promote angiogenesis or regeneration of the damaged endothelium (14). Since there is no specific and distinctive marker for EPC, the panel of surface cell markers is usually used for their identification. Traditionally, co-expression of CD34/VEGFR2(KDR)/CD 133 surface markers is used to identify human circulating EPCs (13). However, more "mature” forms of EPC progressively lose CD133 expression, which leave more committed EPCs with CD34+VEGFR2+ phenotype.

\section{EPC CAPTURING STENTS - DEVELOPMENT}

Among many antibody-targeted surface markers of circulating EPC potentially capable of capturing these cells from circulation, CD34 has been shown to be the most specific molecule in this setting (15). CD34 is a transmembrane glycoprotein expressed on the cell surface, important in regulation of cells' proliferation and differentiation (16). It is traditionally described as hematopoietic stem cells marker, but its expression is proven on several non-hematopoietic progenitor lineages, such as vascular endothelial progenitors (17), epithelial progenitors (18) and embryonic fibroblasts (19). CD34 is considered to be "pan-endothelial" marker, expressed on early and mature vascular endothelial cells. Along with CD133 and VEGFR2, CD34 counts into crucial markers for identification of EPCs (13).

EPC capturing stents are designed in such a manner that immobilized, monoclonal, antihuman CD34 antibodies are attached to the luminal surface of the stent, where they target and capture CD34 immunopositive (CD34 ${ }^{+}$) circulating cells. Initially, it was hypothesized that the "captured” EPCs incorporate into the vessel wall, and further differentiate into new endothelial cells. Additional mechanism was proposed, where the recruited EPCs adhered to denuded endothelium, secreted pro-angiogenic factors that stimulated resident endothelial cell to proliferate and migrate in order to form intimal layer $(20,21)$.

The first stent coated with anti-CD34 antibodies was tested in 2003 on experimental murine model (22). This novel therapeutic strategy resulted in rapid endothelization of implanted stents, while adherent CD34 ${ }^{+}$cells were present on the stent surface after 1 hour of incubation. Experimental studies that followed aimed at comparing EPC capturing stents to BMS/DES.

The comparison of EPC capturing stent with BMS in the animal model also showed positive results for EPC strategy (23). Early endothelization on the $2^{\text {nd }}$ day was significantly higher with anti-CD34 antibody covered stents compared to BMS (68\% vs. 53\%), although the endothelization rate was similar on the $5^{\text {th }}$ day(above 95\%). Additionally, neointimal thickness did not show difference between the two stent groups on $28^{\text {th }}$ and $90^{\text {th }}$ day. Greater rate of endothelization by EPC capturing stent vs. BMS on the $7^{\text {th }}$ day was also confirmed by scanning electron microscope (SEM) and quantitative PCR in rabbit aorta and ilio-femoral injury model (24).

Nakazawa et al. (25) assumed that the implantation of EPC capturing stent (Genous stent Technology, OrbusNeich Medical, Fort Lauderdale, Florida) could intensify endothelization of sirolimus-eluting stent (SES) compared to SES alone. That hypothesis was tested on porcine coronary arteries where endothelization was confirmed by CD31 expression (another well-known endothelial cell marker) using confocal microscopy and SEM. Fourteen days after single stent implantation, the highest percentage of stent endothelization was recorded in EPC capturing stent (99\%), the endothelial 
cells' coverage of overlapping segments (SES with EPC capturing stent) was $79 \%$, while the endothelization percentage was the lowest in SES alone (55\%). Examining different stent overlapping combinations, authors noted that the endothelization of overlapping segment was the highest with EPC + EPC stent (95\%), lower, but still significantly high, in EPC + SES (79\%) compared to overlapping segment of SES + SES (36\%). These results confirmed greater re-endothelization success of EPC capturing stents, regardless of overlapping with SES. Granada et al. (26) confirmed these results on a swine model, observing greater endothelial maturation on EPC capturing stent than on SES by quantitative CD31 expression with confocal microscopy. Additionally, optical coherence tomography (OCT) and histological analysis showed no difference in neointimal thickness between EPC capturing stent, SES and everolimus-eluting stent (EES) on the $28^{\text {th }}$ day.

Tan et al. (27) examined the novel nanocomposite polymer surface (POSS-PCU) as a platform for sequestration of EPC via immobilized anti-CD34 antibodies. The number of EPC colonies was assessed by fluorescence microscopy and SEM, showing no difference between anti-CD34-coated POSS-PCU surface and POSS-PCU surface with no antibodies attached. On the other hand, the presence of antibodies significantly improved hemocompatibility, which resulted in prolonged clotting times, decreased platelet adhesion and activation. These results pointed to the importance of the stent surface and adequate surface-antibody combination to attract, capture EPCs and promote endothelization.

\section{EPC CAPTURING STENTS - CLINICAL TRIALS}

Data from first-in-man clinical trial with EPC capturing stent (Genous ${ }^{\circledR}$ ) were published in 2005 (28). In all 16 enrolled patients with unstable angina or silent ischemia from HEALING-FIM registry complete angiographic and procedural success was accomplished. After 9-month follow-up, major adverse cardiovascular events (MACE) were recorded in only one patient, related to symptom-driven target vessel revascularization, without any evidence of stent thrombosis. HEALING II, a nonrandomized clinical registry study, included more patients with stable coronary artery disease ( $n=63$ ) with quantitative coronary angiography (QCA) and intravascular ultrasound (IVUS) follow-up after 6 and 18 months (29). Significant late regression of neointimal hyperplasia was recorded by QCA between 6 and 18 months of follow-up (24,4\% reduction) as well as with IVUS $(11,4 \%$ reduction). Reduction in neointimal hyperplasia correlated with the number of circulating EPC, where patients with lower EPC titers at 6-month follow-up had greater late lumen loss compared with patients with normal EPC titers. This finding was suggestive of EPC-mediated vascular repair response.

Since the authors of HEALING II study observed beneficial effects of statin therapy on the number of circulating EPC and improved angiographic outcomes, HEALING IIB study tested the efficacy and safety of Genous stent in conjunction with the optimal statin therapy to induce and maximize EPC recruitment (30). Despite statin therapy, results in late lumen loss were similar to HEALING II data. However, statin therapy indeed increased the number of circulating EPCs by 5.6fold. The same year, data from the largest Genous stent eHEALING registry were published with 4939 stable patients included to obtain the "real world" data (31). After 12month follow-up, the rate of target vessel failure (defined as target vessel-related cardiac death or myocardial infarction, and target vessel revascularization) was $8.4 \%$, while the incidences of target lesion revascularization and stent thrombosis were low (5.7\% and $1.1 \%$, respectively).

Wohrle et al. (32) tested whether combination of paclitaxel-coated balloon with EPC capturing stent could improve endothelization and reduce neointimal proliferation in 120 patients with native coronary arteries. Treatment with paclitaxel-coated balloon with EPC stent was superior to EPC alone in terms of in-stent late lumen loss after 6 months. Additionally, clinical events (composite of cardiac death, myocardial infarction due to target vessel or target lesion revascularization) were reduced from $17.2 \%$ to $4.8 \%$, with no stent thrombosis recorded in both groups.

EPC capturing stents proved their feasibility and safety in patients with ST-elevation acute myocardial infarction (STEMI) without cardiogenic shock during primary PCI (33). This clinical study enrolled 120 STEMI patients, where the majority of them (95\%) achieved Thrombolysis in Myocardial Infarction (TIMI) flow 3 after PCI. MACE rate was $1.6 \%$ at the hospital, $4.2 \%$ after 30 days, 5.8\% after 6 months, and $9.2 \%$ after 1 year of follow-up. Two patients experienced acute and subacute stent thrombosis, with no occurrence of late stent thrombosis.

Choi et al. (34) reported significantly improved microvascular dysfunction 6 months after the implantation of EPC capturing stent compared to DES (zotarolimus- or everolimus-eluting stent). Although coronary flow reserve (CFR) was not significantly different among different stent groups after 6-month follow-up, patients with EPC stent had significantly lower index of microvascular resistance (IMR) compared to patients with second-generation DESs.

Implantation of EPC capturing stent in patients with high risk of restenosis gave better long-term results than paclitaxel-eluting stent. After 1-year follow-up, target vessel failure was $17.3 \%$ in EPC stent group vs. $10.5 \%$ in paclitaxeleluting group (35). However, 4 patients in paclitaxel-group had definitive stent thrombosis, with no stent thrombosis occurring in EPC stent-group. After 2-year follow-up, the difference in target vessel failure remained higher in EPC-group than in paclitaxel-group, although the difference was nonsignificant (20.4\% vs. $15.8 \%$, respectively) (36).

Chong et al. (37) reported the trend towards lower MACE rate with EPC capturing stent compared with sirolimus-eluting bioabsorbable polymer stent and BMS in patients with 
acute myocardial infarction treated with primary PCI at 2year follow-up (13.7\% vs. $15.1 \%$ vs. 19.7\%). The largest study with STEMI patients treated with EPC stent $(n=321)$ reported cumulative MACE rate of $8.1 \%$ after 30 days, $10 \%$ after 6 months and 12.2\% after 1-year follow-up (38). There was no evidence of late stent thrombosis, while one patient had acute stent thrombosis and two patients had subacute stent thrombosis.

On the other hand, HEALING registries initially observed that EPC capturing stent did not decrease late lumen loss to the same extent observed for DES (29, 39, 40). The HEALING IIB study, as well as eHEALING registry, confirmed these findings, with late lumen loss being higher with EPC capturing stents than observed for DES $(30,31)$, and also observed these results when comparing EPC capturing stents to newer DES generation $(35,41)$. These results initiated novel, modified EPC stent strategies.

Combining abluminal, bioabsorbable polymer with immobilized luminal anti-CD34 antibody along with drug-eluting stent properties emerged as an interesting therapeutic approach that could enhance in situ endothelization and diminish the risk of late stent thrombosis. Well-designed Combo stent (OrbusNeich, Hoevelaken, the Netherlands) which merged bioabsorbable polymer, CD34 antibody coating and sirolimus as an eluting agent, initially showed less neointimal thickness with a higher degree of platelet and endothelial cell adhesion molecule expression compared to SES and EES in the animal model (42). Afterwards, Combo stent was compared to paclitaxel-eluting stent in 183 patients with single de novo native coronary artery lesion (43). This EPC capturing Combo stent proved non-inferior when analyzing in-stent late lumen loss after 9 months and MACE after 12-month follow-up. Additionally, no stent thrombosis was reported in either stent group. Results from the REMEDEE registry showed excellent results with Combo stent in routine clinical practice (44). One-year results of 1000 all-comers patients with implanted Combo stent showed the rate of target lesion failure of $5.7 \%$, cardiac death of $1.7 \%$, target vessel myocardial infarction of $0.7 \%$, and target lesion revascularization of $4.4 \%$. Promising results have also been reported with the Combo stent implantation in patients with acute coronary syndrome (45) and diabetic patients (46).

Recently published results from the HARMONEE (The Japan-United States of America Harmonized Assessment by Randomized Multicenter Study of OrbusNEich's Combo StEnt) registration study demonstrated the efficacy of Combo stent compared to Xience, contemporary DES (47). A total of 572 patients with ischemic coronary disease and non-ST elevation acute coronary syndrome were randomized to receive Combo stent or Xience stent. The primary endpoint was target vessel failure, with estimated value of $9 \%$ in the
Combo-group. However, target vessel failure was even lower than expected in patients receiving EPC-stent (7\%) after 12 months vs. $4.2 \%$ in DES-group, meeting the non-inferiority study goal. Additionally, OCT after 12 months showed significantly better stent coverage with healthy tissue with Combo stent than with Xience (91.3 vs. 74.8), with more homogenous texture of neointima again with Combo stent (81.2\% vs. $68.8 \%$, respectively).

A lot is expected from the ongoing SORT OUT $\mathrm{X}$ trial that aims to compare efficacy and safety of Combo stent with contemporary, third-generation SES, with planned 3140 enrolled patients in a population-based setting, using registry detection of clinically driven events (48).

\section{FUTURE PERSPECTIVE}

Balancing thrombotic and hemorrhagic risk is essential in patients with stent implantation during PCI. Although DES significantly reduced the rate of in-stent restenosis compared to BMS, late stent thrombosis appeared as one of the late DES complications. One of the most significant predictors of late stent thrombosis is endothelial coverage. Therefore, improving endothelization by EPC capturing stents is an intriguing approach that showed promising results in clinical trials with comparable efficacy to BMSs and DESs.

On the other hand, not all DESs with delayed stent healing exhibit late stent thrombosis $(49,50)$. This late complication can occur late after the cytostatic/cytotoxic drug has eluted from the stent. Another proposed mechanism for late stent thrombosis could be the chronic vascular irritation or endothelial dysfunction induced by stent, drug or coating (51, 52). Therefore, future investigation and trials might be focused on improving endothelial dysfunction, parallel to enhancing endothelization.

Choosing a specific surface marker for EPC seems to be the greatest obstacle in this research field. Antibodies attached to the coronary stent should have high affinity, specificity and selectivity to capture EPCs, without binding to other blood cells. Since EPC are sparsely present in the blood flow, such ideal capture molecule should be able to promote EPC mobilization, or even their proliferation.

"Pro-healing” stent technology is a promising therapeutic approach that could significantly reduce the long-term risk of in-stent thrombosis by improving endothelization. On the other hand, this technology could shorten or even eliminate the DAPT treatment and benefit high-risk patients. 


\section{REFERENCES}

1. Buccheri D, Piraino D, Andolina G, et al. Understanding and managing in-stent restenosis: a review of clinical data, from pathogenesis to treatment. J Thorac Dis 2016; 8(10): E1150-62.

2. Borhani S, Hassanajili S, Tafti SHA, Rabbani S. Cardiovascular stents: overview, evolution, and next generation. Prog Biomater 2018; 7: 175-205.

3. Lowe HC, Oesterle SN, Khachigian LM. Coronary instent restenosis: Current status and future strategies. JACC 2002; 39(2): 183-93.

4. Moses JW, Leon MB, Popma JJ, et al. Sirolimus-eluting stents versus standard stents in patients with stenosis in a native coronary artery. NEJM 2003; 349(14): 1315-23.

5. Stone GW, Ellis SG, Cox DA, et al. A polymer-based, paclitaxel-eluting stent in patients with coronary artery disease. NEJM 2004; 350(3): 221-31.

6. Joner M, Nakazawa G, Finn AV, et al. Endothelial cell recovery between comparator polymer-based drugeluting stents. JACC 2008; 52(5): 333-42.

7. van Beusekom HM, Sorop O, van den Heuvel M, et al. Endothelial function rather than endothelial restoration is altered in paclitaxel-as compared to bare metal-, sirolimus and tacrolimus-eluting stents. EuroIntervention 2010; 6(1): 117-25.

8. Farb A, Boam AB. Stent thrombosis redux - the FDA perspective. NEJM 2007; 356(10): 984-7.

9. Daemen J, Wenaweser P, Tsuchida K, et al. Early and late coronary stent thrombosis of sirolimus-eluting and paclitaxel-eluting stents in routine clinical practice: data from a large two-institutional cohort study. Lancet 2007; 369: 667-78.

10. Finn AV, Nakazawa G, Joner $M$, et al. Vascular responses to drug eluting stents importance of delayed healing. Arterioscler Thromb Vasc Biol 2007; 27(7): 1500-10.

11. Virmani R, Guagliumi G, Farb A, et al. Localized hypersensitivity and late coronary thrombosis secondary to a sirolimus-eluting stent: should we be cautious? Circulation 2004; 109: 701-5.

12. Nakazawa G, Otsuka F, Nakano M, Vorpahl M, Yazdani SK, Ladich E, et al. The pathology of neoatherosclerosis in human coronary implants bare-metal and drug-eluting stents. J Am Coll Cardiol 2011; 57(11): 1314-22.

13. Asahara T, Murohara T, Sullivan A, et al. Isolation of putative progenitor endothelial cells for angiogenesis. Science 1997; 275: 964-7.

14. Asahara T, Masuda H, Takahashi T, et al. Bone marrow origin of endothelial progenitor cells responsible for postnatal vasculogenesis in physiological and pathological neovascularization. Circ Res 1999; 85(3): 221-8.

15. Plouffe BD, Kniazeva T, Mayer JE Jr, et al. Development of microfluidics as endothelial progenitor cell capture technology for cardiovascular tissue engineering and diagnostic medicine. FASEB J 2009; 23(10): 3309-14.
16. Rakocevic J, Orlic D, Mitrovic-Ajtic O, et al. Endothelial cell markers from clinician's perspective. Exp Mol Pathol 2017; 102(2); 303-13.

17. Fina L, Molgaard HV, Robertson D, Bradley NJ, Monaghan P, Delia D, et al. Expression of the CD34 gene in vascular endothelial cells. Blood 1990; 75(12): 2417-26.

18. Tumbar T, Guasch G, Greco V, et al. Defining the epithelial stem cell niche in skin. Science. 2004; 303: 359-63.

19. Brown J, Greaves MF, Molgaard HV. The gene encoding the stem cell antigen, CD34, is conserved in mouse and expressed in haemopoietic progenitor cell lines, brain, and embryonic fibroblasts. Int Immunol 1991; 3:175-84.

20. Heider KH, Aziz S, Al-Reshidi MA. Endothelial progenitor cells for cellular angiogenesis and repair: lessons learned from experimental animal models. Regen Med 2017; 12(8): 969-82.

21. Chopra H, Hunk MK, Kwong Dl, et al. Insights into endothelial progenitor cells: origin, classification, potentials, and prospects. Stem Cells Int 2018; 18:2018: 9847015.

22. Kutryk MJ, Kuliszewski MA. In vivo endothelial progenitor cell seeding for the accelerated endothelialization of endovascular devices. Am J Cardiol 2003; 92 (6A): 94L-5L.

23. van Beusekom HM, Ertas G, Sorop O, et al. The genous endothelial progenitor cell capture stent accelerates stent re-endothelialization but does not affect intimal hyperplasia in porcine coronary arteries. Catheter Cardiovasc Interv 2012; 79(2): 231-42.

24. Larsen K, Cheng C, Tempel D, et al. Capture of circulatory endothelial progenitor cells and accelerated re-endothelialization of a bio-engineered stent in human ex vivo shunt and rabbit denudation model. Eur Heart J 2012; 33(1): 120-8.

25. Nakazawa G, Granada JF, Alviar CL, et al. Anti-CD34 antibodies immobilized on the surface of sirolimuseluting stents enhance stent endothelialization. JACC Cardiovasc Interv 2010; 3(1): 68-75.

26. Granada JF, Inami S, Aboodi MS, et al. Development of a novel prohealing stent designed to deliver sirolimus from a biodegradable abluminal matrix. Circ Cardiovasc Interv 2010; 3: 257-66.

27. Tan A, Goh D, Farhatnia Y, et al. An Anti-CD34 Antibody-Functionalized Clinical-Grade POSS-PCU Nanocomposite Polymer for Cardiovascular Stent Coating Applications: A Preliminary Assessment of Endothelial Progenitor Cell Capture and Hemocompatibility. PLoS One 2013; 8(10).

28. Aoki J, Serruys PW, van Beusekom H, et al. Endothelial progenitor cell capture by stents coated with antibody against CD34: the HEALING-FIM (healthy endothelial accelerated lining inhibits neointimal growth-first in man) registry. J Am Coll Cardiol 2005; 45(10): 1574-9. 
29. Duckers HJ, Soullie T, den Heijer P, et al. Accelerated vascular repair following percutaneous coronary intervention by capture of endothelial progenitor cells promotes regression of neointimal growth at long term follow-up: final results of the Healing II trial using an endothelial progenitor cell capturing stent (Genous R stent) EuroIntervention 2007; 3: 350-8.

30. den Dekker WK, Houtgraaf JH, Onuma Y, et al. Final results of the HEALING IIB trial to evaluate a bioengineered CD34 antibody coated stent (GenousStent) designed to promote vascular healing by capture of circulating endothelial progenitor cells in CAD patients. Atherosclerosis 2011; 219: 245-52.

31. Silber S, Damman P, Klomp M, et al. Clinical results after coronary stenting with the Genous bio-engineered R stent: 12month outcomes of the eHEALING (Healthy Endothelial Accelerated Lining Inhibits Neointimal Growth) worldwide registry. EuroIntervention 2011; 6(7): 819-25.

32. Wohrle J, Birkemeyer R, Markovic S, et al. Prospective randomised trial evaluating a paclitaxel-coated balloon in patients treated with endothelial progenitor cell capturing stents for de novo coronary artery disease. Heart 2011; 97: 1338-42.

33. Co M, Tay E, Lee $\mathrm{CH}$, et al. Use of endothelial progenitor cell capture stent (Genous bio-engineered $\mathrm{R}$ stent) during primary percutaneous coronary intervention in acute myocardial infarction: intermediate-to long-term clinical follow-up. Am Heart J 2008; 155(1): 128-132.

34. Choi WG, Kim SH, Yoon HS, et al. Impact of an endothelial progenitor cell capturing stent on coronary microvascular function: comparison with drug-eluting stents. Korean J Intern Med 2015; 30(1): 42-8.

35. Beijk MA, Klomp M, Verouden NJ, et al. Genous endothelial progenitor cell capturing stent vs. the Taxus Liberte stent in patients with de novo coronary lesions with a high-risk of coronary restenosis: a randomized, single-centre, pilot study. Eut Heart J 2010; 31(9): 105564.

36. Beijk MA, Klomp M, van Geloven N, et al. Two-year follow-up of the Genous endothelial progenitor cell capturing stent versus the taxus liberte stent in patients with de novo coronary artery lesions with a high-risk of restenosis: a randomized, single-center, pilot study. Catheter Cardiovasc Interv 2011; 78(2): 189-95.

37. Chong E, Poh KK, Liang S, et al. Two-year clinical registry follow-up of endothelial progenitor cell capture stent versus sirolimus-eluting bioabsorbable polymercoated stent versus bare metal stents in patients undergoing primary percutaneous coronary intervention for ST elevation myocardial infarction. J Interv Cardiol 2010; 23(2): 101-8.

38. Lee YP, Tay E, Lee CH, et al.Endothelial progenitor cell capture stent implantation in patients with ST segment elevation acute myocardial infarction: one year followup. EuroIntervention 2010; 5(6): 698-702.

39. Walter DH, Rittig K, Bahlmann FH, et al. Statin therapy accelerates reendothelialization: a novel effect involving mobilization and incorporation of bone marrow-derived endothelial progenitor cells. Circulation 2002; 105(25): 3017-24.

40. Duckers HJ, Silber S, de Winter R, et al. Circulating endothelial progenitor cells predict angiographic and intravascular ultrasound outcome following percutaneous coronary interventions in the Healing II trial: evaluation of an endothelial progenitor cell capturing stent. EuroIntervention 2007; 3(1): 67-75.

41. Garg S, Duckers HJ, Serruys PW. Endothelial progenitor cell capture stents: will this technology find its niche in contemporary practice? Eur Heart J 2012; 31: 10321035.

42. Granada JF, Inami S, Aboodi MS, et al. Development of a novel prohealing stent designed to deliver sirolimus from a biodegradable abluminal matrix. Circ Cardiovasc Interv 2010; 3(3): 257-66.

43. Haude M, Lee SW, Worthley SG, et al. The REMEDEE trial: a randomized comparison of a combination sirolimus-eluting endothelial progenitor cell capture stent with a paclitaxel-eluting stent. JACC Cardiovasc Interv 2013; 6: 334-43.

44. Woudstra P, Kalkman DN, den Heijer P, et al. 1-year results of the REMEDEE registry: Clinical outcomes after deployment of the abluminal sirolimus-coated bioengineered (combo) stent in a multicenter, prospective all-comers registry. JACC Cardiovasc Interv 2016; 9: 1127-34.

45. Kalkman DN, Woudstra P, Lu H, et al. Evaluation of clinical outcomes after COMBO stent treatment in patients presenting with acute coronary syndrome. Catheter Cardiovasc Interv 2017; 90: E31-7.

46. Kalkman DN, Woudstra P, den Heijer P, et al. One year clinical outcomes in patients with insulin-treated diabetes mellitus and non-insulin-treated diabetes mellitus compared to non-diabetics after deployment of the bio-engineered COMBO stent. Int J Cardiol 2017; 226: 60-4.

47. Saito S, Krucoff MW, Nakamura S, et al. Japan-United States of America Harmonized Assessment by Randomized Multicentre Study of OrbusNEich's Combo StEnt (Japan-USA HARMONEE) study: primary results of the pivotal registration study of combined endothelial progenitor cell capture and drug-eluting stent in patients with ischaemic coronary disease and non-ST-elevation acute coronary syndrome. Eur Heart J 2018; 29(26): 2460-8.

48. Jakobsen L, Christiansen EH, Maeng $\mathrm{M}$, et al. Randomized clinical comparison of the dual-therapy CD34 antibody-covered sirolimus-eluting Combo stent with the sirolimus-eluting Orsiro stent in patients treated with percutaneous coronary intervention: Rationale and study design of the Scandinavian Organization for Randomized Trials with Clinical Outcome (SORT OUT) X trial. Am Heart J 2018; 202: 49-53.

49. Joner M, Finn AV, Farb A, et al. Pathology of drugeluting stents in humans: delayed healing and late thrombotic risk. J Am Coll Cardiol 2006; 48: 193-202. 
50. van Beusekom HM, Saia F, Zindler JD, et al. Drugeluting stents show delayed healing: paclitaxel more pronounced than sirolimus. Eur Heart J 2007; 28: 974-9.

51. Brancati MF, Burzotta F, Trani C, et al. Coronary stents and vascular response to implantation: literature review. Pragm Obs Res 2017; 8: 137-48.
52. Juni RP, Duckers HJ, Vanhoutte PM, et al. Oxidative stress and pathological changes after coronary interventions. J Am Coll Cardiol 2013; 61(14): 1471-81. 